\title{
YOGA IN THE LIFE OF A CANCER PATIENT - A NARRATIVE REVIEW
}

\section{JOGA W ŻYCIU PACJENTA Z NOWOTWOREM - PRZEGLĄD ŹRÓDEE}

\author{
Andrea Obročníková ${ }^{1(\mathrm{~A}, \mathrm{C}, \mathrm{D}, \mathrm{E}, \mathrm{F})}$, L’udmila Majerníková $^{1(\mathrm{~A}, \mathrm{E})}$
}

${ }^{1}$ Department of Nursing, University of Prešov, Prešov, Slovakia

Authors' contribution Wkład autorów: A. Study design/planning zaplanowanie badań B. Data collection/entry zebranie danych C. Data analysis/statistics dane - analiza i statystyki D. Data interpretation interpretacja danych E. Preparation of manuscript przygotowanie artykułu F. Literature analysis/search wyszukiwanie i analiza literatury G. Funds collection zebranie funduszy
Tables: 0

Figures: 0

References: 30

Submitted: 2021 Jul 9

Accepted: 2021 Sep 1

\section{Summary}

Yoga exists in the context of health care, complementary therapy, movement training techniques as well as religious philosophy. Many studies suggest yoga is a non-demanding activity that can effectively reduce anxiety, depression, and pain in the adult population with acute and chronic health conditions without adverse effects. Based on the results of numerous studies, yoga intervention can improve mental health and improve the quality of life of cancer patients or survivors. This paper focuses on yoga and its impact on alleviating the symptoms of cancer and the treatment. Based on the reviewed literature, the results of the studies suggest the problem of heterogeneous study design, lack of quantitative findings and lack of evidence regarding the long-term effects of yoga on the personal well-being of cancer patients. Future research should focus on systematic reviews or meta-analyses to provide further evidence on the type and effectiveness of yoga during or after cancer treatment for specific cancers.

Keywords: yoga, complementary therapies, quality of life, cancer, treatment

\section{Streszczenie}

Joga istnieje w kontekście opieki zdrowotnej, terapii wspomagającej, technik treningu ruchowego oraz filozofii religijnej. Wiele badań wskazuje na jogę jako niewymagającą czynność, która może skutecznie zmniejszyć lęk, depresję i ból u dorosłej populacji w ostrych i przewlekłych stanach chorobowych bez negatywnych skutków. Według licznych wyników badań, zastosowanie jogi może poprawić zdrowie psychiczne oraz polepszyć jakość życia pacjentów z nowotworem lub osób, które wygrały walke z chorobą. W niniejszym artykule omówiono jogę i jej wpływ na łagodzenie objawów choroby nowotworowej oraz jej leczenie. Na podstawie przeanalizowanej literatury, wyniki prezentowanych badań wskazują na problem niejednorodnego projektu badań, braku wyników ilościowych oraz dowodów na długofalowy wpływ jogi na samopoczucie pacjentów onkologicznych. Dalsze badania powinny opierać się na systematycznych przeglądach lub meta-analizach mających na celu dostarczenie kolejnych dowodów na rodzaj i skuteczność jogi podczas lub po zakończeniu terapii w przypadku określonych nowotworów.

Słowa kluczowe: joga, terapie wspomagające, jakość życia, nowotwór, leczenie

\section{Introduction}

Diagnosis and treatment of cancer poses psychological or physical threats to patients during longterm hospitalization, which seriously affect the overall quality of life (QoL) for patients. Fear, anxiety, along with annoying thoughts related to cancer, age and financial status can together lead to an increased risk of psychological distress. Impaired perceptions of QoL affect indigestion and pain as well. These factors can lead to a feeling of helplessness, despair, sleep disturbances, adverse anti-tumor immune response, earlier relapse, worsening of concomitant disease and lower overall survival rates [1]. The long-term treatment process is associated with the accumulation of various disease states and difficulties such as appearance changes, infertility, sexual dysfunction, hair loss, fatigue, nausea, vomiting, pain, infections, decreased blood levels and others [2]. There is also a significant psychological burden, fear of the unknown, of the future, fear of suffering and pain, feelings of loneliness, fear of death [3]. QoL can be significantly endangered. Mental and physical difficulties in conjunction with other situational stressors and daily worries in turn reduce the patient's ability to tolerate pain and symptoms of the disease. In many cases, this leads to increased drug dependence, depressive disorders, lack of will to live, lowering the pain threshold, sleep disorders, increased difficulty and more frequent relapses. This burden in cancer patients is associated with reduced functionality, increased disability and deteriorating

Obročníková A, Majerníková L. Yoga in the life of a cancer patient - a narrative review. Health Prob Civil. 2021; 15(3): 218-224.

https://doi.org/10.5114/hpc.2021.108998

Address for correspondence / Adres korespondencyjny: Andrea Obročníková, Department of Nursing, University of Prešov, Partizánska 1, 08001 Prešov, Slovakia, e-mail: andrea.obrocnikova@unipo.sk, phone: +421517563110

ORCID: Andrea Obročníková https://orcid.org/0000-0002-2708-393X, L'udmila Majerníková https://orcid.org/0000-0001-7748-9519

Copyright: (C) Pope John Paul II State School of Higher Education in Biała Podlaska, Andrea Obročníková, L'udmila Majerníková. This is an Open Access journal, all articles are distributed under the terms of the Creative Commons Attribution-NonCommercial-ShareAlike 4.0 International (CC BY-NC-SA 4.0) License (http:// creativecommons.org/licenses/by-nc-sa/4.0/), allowing third parties to copy and redistribute the material in any medium or format and to remix, transform, and build upon the material, provided the original work is properly cited and states its license. 
QoL. In some patients, the cancer-related consequences subside; however, persistent and delayed effects require survivors to gain long-term symptom management [4]. In clinical practice cases are encountered where toxicity of cancer therapy reduces the ability of patients to complete treatment as prescribed protocol and the ability to perform primary activities (food intake, mobility, exercise, grooming, dressing, toilet use, etc.) or secondary activities such as work, family activities and celebrations. The ability to create or complete daily activities is often impaired. In severe cases, therapeutic side effects can significantly increase patient morbidity and mortality.

Discovering effective treatments for oncological diseases is one of the highest priorities of research institutes and institutes of experimental oncology globally [5]. Today, we are seeing a shift from cancer treatment that relies only on the destruction of malignant cells to holistic cancer treatment and symptom management. QoL is crucial when planning the treatment process. Influencing the QoL can lead to improved social, emotional, physical and mental health. However, making the necessary life changes is the responsibility of the patient [1]. The prevalence of integrative medicine approaches has transformed patient care in many specialties, especially oncology. Integrative oncology as a developing discipline in cancer care combines conventional therapies and evidence-based Complementary and Alternative Medicine (CAM) practices. CAM practices include whole medical systems (Ayurveda, Chinese traditional medicine, homeopathy and naturopathy); mind-body medicine (yoga, meditation, relaxation, visualization/imagery, cognitive therapy, aromatherapy, dance, healing touch, hypnosis, music, art, prayer, etc.); biologically based practices (dietary supplements, herbal products, shark cartilage, etc.); manipulative and body-based practices (acupressure, acupuncture, chiropractic, massage) and energy medicines (Qi gong, Reiki, therapeutic touch, electromagnetic fields, etc.) [6]. Using yoga as a CAM is proving to be beneficial and gaining more popularity for health-related benefits. The mind-body medicine element of CAM, is comprised of a wide range of techniques, which gradually harmonizes the body and mind.

Several studies have shown that yoga reduces stress, depression, and anxiety, tiredness (fatigue), changes cellular area by genomic alteration and enhances cellular immunity [7,8], and improves the quality of sleep, mood and spiritual wellbeing for some cancer patients. Most studies suggest that yoga may be beneficial for patients and it is recommended by several guidelines including the American Society of Medical Oncology (ASCO) endorsed the Society for Integrative Oncology (SIO)'s guideline for integrative therapies during and after treatment for breast cancer; and The National Comprehensive Cancer Network (NCCN) included the practice of yoga for improving some areas of survivorship and for reducing cancer-related distress and fatigue.

\section{Aim of the work}

The aim of this paper is to highlight the benefits of yoga as a complementary method of cancer treatment by reviewing the scientific literature. The review uses Internet information resources, and scientific databases in the field of biomedicine, alternative medicine and nursing. This article is for informational purposes only, therefore, it is an attempt to synthesize existing knowledge on the subject.

\section{Brief description of the status of knowledge}

Yoga is a mind-body exercise, a combination of physical poses with breathing and meditation [8]. Yoga, the therapy of mind and body, is divided into three groups: balance of the body (asanas), breathing techniques (pranayama) and exercises focused on attention (meditation). These three components are based on several oriental traditions from India (classical or tantra yoga), Tibet (Tibetan) or China (Chi Kung, Tai Chi). There are many different styles and types of yoga. Gentle hatha yoga and restorative (regenerative) yoga are two systematic methods of yoga that are very popular in the world and are more accepted by traditional Western medicine. Gentle hatha yoga focuses on physical positions while restorative yoga focuses on total relaxation. By combining these two methods, we can reduce the toxicity associated with cancer treatment [5]. Several studies in the cancer-free population have described the positive effects of yoga on the body, including motor skills, perception, improving cardiopulmonary function, flexibility, stiffness and joint pain [4,9-17]. A comparison of the effects of yoga asanas with regular exercise shows that yoga, as well as exercise, improves the level of health in healthy people and in people with chronic diseases [9].

Many clinical studies investigating the use of yoga as a complementary method in cancer patients indicate that yoga reduces stress, depression and anxiety, and increases cellular immunity [1,18]. Research evidence confirms a reduction in chemotherapy-related side effects of fatigue, sleep disturbances, nausea and vomiting, constipation, sleep problems and pain $[1,19]$. The review study highlights the regenerative effects of yoga in patients. Yoga can regulate anti-tumor and anti-inflammatory immune responses after surgery, reduce genotoxic stress, normalize stress hormones (saliva secretion) and edit rhythm of cortisol, thereby regulating the 
neuroendocrine immune axis and reducing stress affecting the hypothalamic-pituitary-adrenal axis $[2,7,8,20]$. There are many forms of yoga, including Hatha Yoga, Iyengar Yoga, Integrated Yoga, Sudarshan kriya Yoga, Pranayama, Mindfulness-Based Stress Reduction (Buddhist meditation), Viniyoga, Tibetian Yoga and others. The variety of yoga types and the research methods provide differences in results on the effects of yoga. The goal of yoga is to gain an awareness of relaxation to help reduce intrusive thoughts that can lead to increased anxiety and depression. Cancer patients practicing yoga have found that activities of daily life are easier to cope with [1].

\section{Yoga and selected cancers}

The effect of yoga has been observed in oncological diseases of the breast, lungs, brain and blood in a number of studies.

\section{Breast cancer}

Breast cancer is one of the most common oncogynecological diseases diagnosed in women [21]. Diagnosis and treatment of breast cancer brings a number of physical, mental and emotional difficulties. Patients are treated for lengthy periods with multimodal treatments and it seriously affects the QoL of cancer patients [2]. Despite medical advances that increase the survival rate of breast cancer patients, they continue to suffer painful symptoms. If the patient is unable to effectively manage the perceived discomfort that occurs in relation to the symptom, it can lead to anxiety and depression. Such conditions can significantly affect the patient's prognosis in terms of QoL, emotional state, social isolation or self-care. There is evidence that pain in cancer patients is not often successfully treated. Patients and healthcare professionals report that problems, such as lack of energy and depression, persist due to increased treatment aggression or deterioration $[4,22]$. The main task is to recognize and deal with the symptoms associated with cancer. Several decades ago, the suffering of breast cancer patients was reduced by various psychotherapeutic and cognitive-behavioral interventions [23].

According to research by Vadiraj et al. [20], yoga has a beneficial effect on improving mood and QoL. The study involved 88 women with recently diagnosed breast cancer who were randomly assigned to receive yoga $(n=44)$ or brief supportive therapy $(n=44)$ prior to their radiotherapy treatment. The 75 women ranged in age from 30 to 70 years (yoga $n=42$; control $n=33$ ), completed their prescribed radiation therapy (of 6-weeks) and follow-up assessment. Each intervention was performed separately with a therapist. The yoga intervention included easy yoga postures, various breathing procedures (pranayama) and relaxation exercises. Participants participated in personal yoga sessions at least three times a week during the 6-week radiotherapy period and other days they could practice at home (instructions for home exercise were recorded on an audio tape). All sessions lasted for one hour and were performed by a trained yoga therapist before or after radiotherapy. The control group with supportive therapy took part in three to four consultation meetings with a trained social worker in the hospital over a period of 6-weeks (once in 10 days for 15 minutes sessions). The goal of supportive therapy was education, strengthening social support and preparing to manage the disease. The intervention group underwent 18 to 24 yoga sessions. The Positive and Negative Affect Schedule (PANAS) scale was used to measure changes in emotional state. The scale contains two subscales: positive affect (PA) which reflects a state of high energy, full concentration and pleasurable engagement; negative affect (NA) which reflects a perception of distress with a variety of aversive mood states and the European Organization for Research and Treatment of Cancer-Quality of Life C30 (EORTCQoL C 30) was used to measure QoL. The results showed improvement in PA (Mean difference $\pm S E$, $p$ value, $95 \% \mathrm{CI})(4.52 \pm 1.7, \mathrm{p}=0.007,1.25$ to 7.8$)$ and decrease in NA $(-8.95 \pm 2.3, \mathrm{p}<0.001$, -13.4 to -4.4$)$, improvement in emotional function $(15.88 \pm 4.75, p=0.001,6.45$ to 25.33 ) and cognitive function $(9.8 \pm 4.35, p=0.03,1.2$ to 18.5 ) in both the compared groups (yoga vs. control) following interventions. Following the intervention, the yoga group had improvement in positive affect $(-3.81 \pm 1.1, \mathrm{p}<0.001,1.75$ to 5.89$)$, a decrease in negative affect $(9.25 \pm 1.45, \mathrm{p}<0.001,6.4$ to 12.1$)$, and improvement in emotional $(-18.63 \pm 2.8, \mathrm{p}<0.001,-24.3$ to -12.9$)$ and cognitive function $(5.27 \pm 2.69, \mathrm{p}=0.05,-10.63$ to -0.007$)$. A significant decrease in negative affect (3.37 $\pm 1.5, p=0.02,0.49$ to 6.24$)$, improvement in physical function $(-6.23 \pm 2.9, p=0.03,-11.9$ to -0.49$)$ and emotional function $(-7.66 \pm 2.88, p=0.009,-13.4$ to -1.9$)$ was also observed in the control group following intervention. Experiencing positive emotions and suppressing negative feelings can be achieved by using interventions such as yoga, exercise and stress reduction activities. In this study, positive changes in emotional state contributed to improving the perceived QoL. The decrease in negative affect was related to improvement in physical function $(p=0.004)$, emotional function $(p<0.01)$ and social function $(p=0.008)$ and improvement in positive affect was related to improvement in all dimensions of QoL [20]. 
Cramer et al. [22] performed a meta-analysis of 24 studies consisting of 2166 women. The women in the studies underwent surgery, chemotherapy or radiotherapy. The aim of the meta-analysis was to test the effectiveness of yoga practice on QoL, mental health and the symptoms associated with breast cancer in women during therapy and after general breast cancer treatment. The studies evaluated QoL, depression, fatigue and sleep disorders using various questionnaires. Compared to yoga as a single exercise, yoga led to an improvement in QoL (MD 0.22; 95\% CI 0.04 to $-0.40 ; 10$ studies, 675 patients), fatigue reduction (MD $-0.48 ; 95 \% \mathrm{CI}-0.75$ to -0.20 ; 11 studies, 883 patients) and reduction of sleep problems (MD $-0.25 ; 95 \% \mathrm{CI}-0.40$ to $-0.09 ; 6$ studies, 657 patients). In four studies, yoga was compared with psychosocial/educational interventions and led to a reduction in depression (MD $-2.29 ; 95 \% \mathrm{CI}-3.97$ to -0.61 ; four studies, 226 patients), anxiety (MD $-2.21 ; 95 \%$ CI -3.90 to -0.52 ; 3 studies, 195 patients) and fatigue (MD $-0.90 ; 95 \%$ CI -1.31 to $-0.50 ; 2$ studies, 106 patients).

\section{Lung cancer}

Lung cancer is one of the most widespread oncological diseases in Slovakia. Approximately 2500 new cases are diagnosed each year and higher amongst men [24]. Cancer treatment can significantly reduce a patient's physical strength and QoL, as well, family members may experience exhaustion and fatigue. Although patients with lung cancer often have more pronounced symptoms and are usually older, yoga is a type of exercise that can be done by almost anyone, so patients can comply. The aim of the study was to evaluate the feasibility and potential efficacy of a yoga intervention for patients with non-small cell lung cancer (NSCLC) and their caregivers. The nasal breathing techniques (pranayama) can be of great benefit to patients suffering from shortness of breath due to chest irradiation [25]. The aim of the study was to find out whether patients with NSCLC would be able to participate in a 15-hour yoga program and whether this would increase their physical fitness, improve independence and improve the QoL of a family caregiver. The study involved 26 cancer patients (67\% stage III) and their caregivers. They were introduced to a 60-minute exercise (one session) that emphasized proper posture and proper breathing. The researchers selected light yoga exercises focused on the chest area, its expansion along with deep breathing. The researchers assessed the patient's and caregiver's QoL at the start of treatment, on the last day of irradiation, and three months later, using the SF-36 instrument. Participants in a pair with a caregiver completed an average of 12 sessions. Significant improvements in fitness, fatigue, sleep, mental health (anxiety, depression) were observed in lung cancer patients and improved vitality and performance in family caregivers. Patients in the yoga group (DY) had clinically significant improvements on the 6-minute walk test compared to the control group (WLC) (means: DY=473 m vs WLC=397 m, d=1.19) and SF-36 physical function (means: DY=38.77 vs WLC=30.88; $d=.66$ ) and social function (means: DY=45.24 vs WLC=39.09; $d=.44$ ) across the follow-up period. Caregivers in the DY group reported marginal clinically significant improvements in SF-36 vitality (means: DY=53.05 vs WLC=48.84; $\mathrm{d}=.39$ ) and role performance (means: $\mathrm{DY}=52.78$ vs $\mathrm{WLC}=48.59$; $\mathrm{d}=.51$ ) relative to those in the WLC group. The authors observed a mild but clinically significant effect on patients' dyspnea. The results showed that patients, even with advanced lung cancer, were able to practice yoga exercises of moderate intensity. Both patients and caregivers saw yoga exercises as an opportunity to break away from bad thoughts associated with cancer and evaluated yoga as a positive new experience they would continue beyond the study [25].

\section{High-grade brain glioma}

Tumors of glial origin are primary intracranial tumors of neuroepithelial tissues and at an advanced stage cause difficulties in the form of headache, nausea, vomiting, mental changes and cognitive impairment [26]. Although the symptomatic burden is high and the prognosis of high-grade glioma is poor, there is still a lack of supportive treatment for this disease. The study by Milbury et al. [27] focused on a dual yoga program for cancer patients with glioma and their caregivers who care about the quality of family life. The sample consisted of patients $(n=5)$ and caregivers $(n=5)$. The mean age of patients was 52 years, $80 \%$ women, $80 \%$ grade IV and caregivers were mainly female (60\%), spouses $(60 \%)$ and mean age was 58 years. The yoga intervention focused on breathing exercises, gentle movements and meditation. The monitored variables included the brain tumor-related symptoms by MD Anderson Symptom Inventory (MDASI), depressive symptoms by Centers for Epidemiological Studies-Depression scale, fatigue by Brief Fatigue Inventory, sleep disturbances by Pittsburgh Sleep Quality Index (PSQI) and overall physical and mental quality of health by 36-item Short-Form Survey (SF-36). The surveyed five couples agreed with the study and completed all sessions and evaluations before and after the dual yoga program (at the end of radiotherapy). The couples attended two or three sessions a week for five to six weeks with one session lasting one hour. After the first meeting, participants received printed material and a DVD that contained the entire yoga program for home exercise. The whole program was 
well tolerated by the participants and no side effects were reported. In patients with brain cancer a clinically significant reduction in cancer symptoms was observed ( $\mathrm{t}=2.32$, $\mathrm{p}=.08$; MDASI mean: pre $=1.75$, post $=1.04)$, along with an alleviation of disturbed sleep $(t=-1.35, p=.10$; PSQI mean: pre $=10.75$, post $=8.00)$, improvement of mental vitality, and a reduction of mental distress (MCS of SF-36 mean: pre $=42.35$, post $=52.34$ ). The caregivers also confirmed the effects of the completed program. Remarkably, the QoL of caregivers had improved mentally (MCS of SF-36 mean: pre $=45.14$, post=51.43), but there was evidence of increased depressive symptoms (CES-D mean: pre $=12.00$, post $=14.40$ ). The authors of the study argue that the program taught participants mindfulness and caregivers could feel patients' grief associated with a poor prognosis of high-grade glioma. The authors consider the supportive care program to be safe, feasible, acceptable, and useful for high-grade glioma patients and their caregivers [27]. This study could be a good starting point for the study of dual behavioral intervention in the symptomatic treatment of patients with brain cancer.

\section{Hematological malignancies}

Treatment of hematological malignancies (chemotherapy, radiotherapy, and/or bone marrow transplantation or stem cells) is often associated with a long hospitalization and a number of common side effects that are sometimes more devastating to a patient's QoL than cancer alone. The most common side effects include physical (fatigue, pain, sleep disorders), psychological (anxiety, depression) and social (loneliness, negative self-image, loss of control and privacy) consequences. Symptoms of inpatient treatment for hematological cancer may adversely affect QoL for years after treatment. Treatment of symptoms during hospitalization requires multidisciplinary interventions to improve long-term QoL. Mascaro et al. [28] studied a four-year program looking at improvement in symptoms that included individualized single yoga therapy session during the treatment of hematological malignancies. Hospitalized patients treated for hematological cancer were given a 40-minute individual yoga therapy. Before and immediately after each session, the yoga therapist recorded the symptoms reported by the patients using a symptom checklist from the validated instrument Functional Assessment of Cancer Therapy Bone Marrow Transplantation (FACT-BMT) version 4. Patients reported a change in symptoms on a Likert-type scale from 0 to 4, with 0 being "not at all" and 4 being "very". Symptoms reported were lack of energy, pain, nausea, side effects, sadness and nervousness. A total of 354 (73\%) sessions were analyzed before and after yoga. Statistical tests indicated that all self-reported symptoms were significantly lower after yoga sessions: fatigue $Z=-9.23, p<0.0001, r=0.50$; nausea $Z=-6.57, p<0.0001, r=0.35$; pain $Z=-6.67, p<0.0001, r=0.36$; annoying side effects $Z=-6.64, p<0.0001, r=0.36$; sadness $Z=-7.11, p<0.0001, r=0.38$; nervousness $Z=-9.61, p<0.0001$, $r=0.52$. Symptoms were also significantly lower after the end of yoga in the analysis of a subgroup of AfricanAmerican patients and a subgroup of male patients. This study also suggests that the integration of yoga therapy into clinical practice was feasible and acceptable for patients [28].

\section{Conclusions}

Incorporating yoga into the lives of cancer patients appears to be an excellent decision. It is a non-invasive method that is not expensive. Oncological disease can have various movement restrictions; after treatment the body is very weak, which leads to lack of movement. Yoga is adaptable in this regard. It is best to start with an experienced certified yoga instructor who will teach the patient the correct techniques. Yoga trainers offer it as a natural way of movement, which brings physical strengthening, balance, stress relief and reduction of anxiety and depression, which contributes to increased QoL, increased self-confidence, restoration of appetite and not least to improve the quality of sleep [29,30]. Many studies confirm that patients prefer team exercises, so people with cancer will make contact with people who have a similar disease. Exercisers support and encourage each other, make new friendships, inform each other about the effects of treatment and a new lifestyle, gain selfconfidence and a sense of belonging. After mastering the correct technique, patients can practice yoga at home. Breathing exercises can be performed by the patient anytime and anywhere, which significantly increases the value of this method [2].

Most of the adverse symptoms of the disease and the side effects of the treatment persist throughout the duration of the patient's disease and it is known that treatment in the early stages can affect the health outcomes later. Treatment of symptoms requires a comprehensive, unique, holistic approach that combines behavior, body and mind [9]. It can be assumed that in the future, yoga may be a preventive intervention that will affect the QoL in the early stages of cancer treatment.

There are several reviews and bibliometric analysis of how yoga increases its value for the possibility of inclusion in the therapeutic plan for cancer patients (after thorough consultation with a doctor). Studies of yoga's 
effectiveness in this paper are characterized by heterogeneity, different types of yoga interventions, different durations, exposures, procedures. Future research should focus on systematic reviews or meta-analyses to provide further evidence on the type and effectiveness of yoga during or after cancer treatment for specific cancers.

\section{Disclosures and acknowledgements}

The research is supported by a grant from the project: KEGA grant assignment Methodology proposal for evaluation of quality of life of patients with multiple sclerosis. ID or registration number of grant, project etc.: 002PU-4/2020.

\section{References:}

1. Raghuram N, Rao RM, Nagendra HR. Integrating yoga in oncology: is the wait over? Indian J Surg Oncol. 2015; 6(4): 325-326. https://doi.org/10.1007/s13193-016-0492-6

2. Rao RM, Vadiraja HS, Nagaratna R, Gopinath KS, Patil S, Diwakar RB, et al. Effect of yoga on sleep quality and neuroendocrine immune response in metastatic breast cancer patients. Indian J Palliat Care. 2017; 23(3): 253-260. https://doi.org/10.4103/IJPC.IJPC_102_17

3. Slováková A. [How to manage cancer. Bedeker health special]. 1st edition. Bratislava: RE-PUBLIC s.r.o.; 2016 (in Slovak).

4. Danhauer SC, Addington EL, Cohen L, Sohl SJ, Van Puymbroeck M, Albinati NK, et al. Yoga for symptom management in oncology: a review of the evidence base and future directions for research. Cancer. 2019; 125(12): 1979-1989. https://doi.org/10.1002/cncr.31979

5. Lin PJ, Peppone LJ, Janelsins MC, Mohile SG, Kamen CS, Kleckner IR, et al. Yoga for the management of cancer treatment-related toxicities. Curr Oncol Rep. 2018; 20(1): 5. https://doi.org/10.1007/s11912-018-0657-2

6. Agarwal RP, Maroko-Afek A. Yoga into cancer care: a review of the evidence-based research. Int J Yoga. 2018; 11(1): 3-29.

7. Sharma H, Datta P, Singh A, Sen S, Bhardwaj NK, Kochupillai V, et al. Gene expression profiling in practitioners of Sudarshan kriya. J Psychosom Res. 2008; 64: 213-218. https://doi.org/10.1016/j.jpsychores.2007.07.003

8. Sharma H, Sen S, Singh A, Bhardwaj NK, Kochupillai V, Singh N, et al. Sudarshan kriya practitioners exhibit better antioxidant status and lower blood lactate levels. Biol Psychol. 2003; 63: $281-291$. https://doi.org/10.1016/S0301-0511(03)00071-1

9. Buffart LM, van Uffelen JG, Riphagen II, Brug J, van Mechelen W, Brown WJ, et al. Physical and psychosocial benefits of yoga in cancer patients and survivors, a systematic review and meta-analysis of randomized controlled trials. BMC Cancer. 2012; 12: 559. https://doi.org/10.1186/1471-2407-12-559

10. Desikachar K, Bragdon L, Bossart C. The yoga of healing: exploring yoga's holistic model for health and wellbeing. Int J Yoga Ther. 2005; 15: 17-39. https://doi.org/10.17761/ijyt.15.1.p501133535230737

11. Kolasinski SL, Garfinkel M, Tsai AG, Matz W, Dyke AV, Schumacher HR. Iyengar yoga for treating symptoms of osteoarthritis of the knees: a pilot study. J Altern Complement Med. 2005; 11: 689-693. https://doi.org/10.1089/acm.2005.11.689

12. Smith C, Hancock H, Blake-Mortimer J, Eckert K. A randomised comparative trial of yoga and relaxation to reduce stress and anxiety. Complement Ther Med. 2007; 15(2): 77-83. https://doi.org/10.1016/j.ctim.2006.05.001

13. Vijayaraghava A, Doreswamy V, Narasipur OS, Kunnavil R, Srinivasamurthy N. Effect of yoga practice on levels of inflammatory markers after moderate and strenuous exercise. J Clin Diagn Res. 2015; 9(6): CC08CC12. https://doi.org/10.7860/JCDR/2015/12851.6021

14. Woolery A, Myers H, Sternlieb B, Zeltzer L. A yoga intervention for young adults with elevated symptoms of depression. Altern Ther Health Med. 2004; 10(2): 60-63.

15. Farinatti PT, Rubini EC, Silva EB, Vanfraechem JH. Flexibility of the elderly after one-year practice of yoga and calisthenics. Int J Yoga Therap. 2014; 24: 71-77. https://doi.org/10.17761/ijyt.24.1.5003007856u32q52

16. Saxena T, Saxena M. The effect of various breathing exercises (pranayama) in patients with bronchial asthma of mild to moderate severity. Int J Yoga. 2009; 2(1): 22-25. https://doi.org/10.4103/0973-6131.53838

17. Yogendra J, Yogendra HJ, Ambardekar S, Lele RD, Shetty S, Dave M, et al. Beneficial effects of yoga lifestyle on reversibility of ischaemic heart disease: caring heart project of International Board of Yoga. J Assoc Physicians India. 2004; 52: 283-289. 
18. Agarwal RP, Maroko-Afek A. Yoga into cancer care: a review of the evidence-based research. Int J Yoga. 2018; 11(1): 3-29.

19. Raghavendra RM, Nagarathna R, Nagendra HR, Gopinath KS, Srinath BS, Ravi BD, et al. Effects of an integrated yoga programme on chemotherapy-induced nausea and emesis in breast cancer patients. Eur J Cancer Care (Engl). 2007; 16(6): 462-474. https://doi.org/10.1111/j.1365-2354.2006.00739.x

20. Vadiraja HS, Rao MR, Nagarathna R, Nagendra HR, Rekha M, Vanitha N, et al. Effects of yoga program on quality of life and affect in early breast cancer patients undergoing adjuvant radiotherapy: a randomized controlled trial. Complement Ther Med. 2009; 17(5-6): 274-280. https://doi.org/10.1016/j.ctim.2009.06.004

21. www.uicc.org [Internet]. Geneva: Union for International Cancer Control (UICC). New Global Cancer Data. 2020 [cited 2021 Jun 16]. Available from: https://www.uicc.org/news/globocan-2020-new-global-can-cerdata

22. Cramer H, Lauche R, Klose P, Lange S, Langhorst J, Dobos GJ. Yoga for improving health-related quality of life, mental health and cancer-related symptoms in women diagnosed with breast cancer. Cochrane Database Syst Rev. 2017; 1(1): CD010802. https://doi.org/10.1002/14651858.CD010802.pub2

23. Dostálová 0. [Mental care of cancer patients]. 1st edition. Praha: Grada a.s.; 2016 (in Czech).

24. NCZI, NOR SR. [Cancer incidence in the Slovak Republic 2012]. 1st edition. Bratislava: NCZI, NOR; 2021 (in Slovak).

25. Milbury K, Mallaiah S, Liao ZX, Shannon V, Yang C, Cohenet L. Randomized controlled trial (RCT) of a dyadic yoga program for lung cancer patients undergoing radiotherapy and their family caregivers. Journal of Clinical Oncology. 2017; 35(31 suppl.): 125-125. https://doi.org/10.1200/JC0.2017.35.31_suppl.125

26. Mravec B. [Nervous system: pathophysiology]. 1st edition. Bratislava: Faber; 2013 (in Slovak).

27. Milbury K, Mallaiah S, Mahajan A, Armstrong T, Weathers SP, Moss KE, et al. Yoga program for high-grade glioma patients undergoing radiotherapy and their family caregivers. Integr Cancer Ther. 2018; 17(2): 332336. https://doi.org/10.1177/1534735417689882

28. Mascaro JS, Waller AV, Wright L, Leonard T, Haack C, Waller EK. Individualized, single session yoga therapy to reduce physical and emotional symptoms in hospitalized hematological cancer patients. Integr Cancer Ther. 2019; 18: 1534735419861692. https://doi.org/10.1177/1534735419861692

29. Yi LJ, Tian X, Jin YF, Luo MJ, Jiménez-Herrera MF. Effects of yoga on health-related quality, physical health and psychological health in women with breast cancer receiving chemotherapy: a systematic review and metaanalysis. Ann Palliat Med. 2021; 10(2): 1961-1975. https://doi.org/10.21037/apm-20-1484

30. Hudáková A, Novotná Z, Németh F, Šuličová A. [Geriatric syndromes as predictors of nursing in geriatrics]. 1 st edition. Prešov: Vydavatel'stvo Prešovskej Univerzity; 2016 (in Slovak). 